\title{
PENINGKATAN KEMAMPUAN APRESIASI PESERTA DIDIK PADA MATERI UPAYA PENGENDALIAN PENYIMPANGAN SOSIAL MELALUI PEMBELAJARAN MODEL BATUK DI SEKOLAH MENENGAH PERTAMA
}

\author{
Muhammad Suhudi \\ SMP Negeri 1 Tekung Kabupaten Lumajang \\ Email: muhammad.suhudi@yahoo.co.id
}

\begin{abstract}
Abstrak
Penelitian ini bertujuan untuk mengetahui peningkatan kemampuan apresiasi peserta didik melalui pembelajaran model batuk pada materi upaya pengendalian penyimpangan sosial di sekolah menengah pertama untuk Penelitian merupakan penelitian tindakan kelas yang dilakukan pada kelas VIII SMP Negeri 1 Tekung dengan jumlah peserta didik 35 peserta didik. Penelitian terdiri atas dua siklus yang meliputi perencanaan, pelaksanaan, pengamatan dan refleksi. Pengumpulan data dengan format pengamatan peserta didik, pengamatan guru, angket, dan kuesioner. Hasilnya, pembelajaran model batuk dapat meningkatkan kemampuan apresiasi peserta didik dalam materi upaya pengendalian penyimpangan sosial.
\end{abstract}

Kata kunci: pembelajaran model batuk, kemampuan apresiasi peserta didik,

\begin{abstract}
The research is purposed to understand the improvement on the appreciation skill of learners through the Batuk learning model on the efforts towards the social deviation control material. The research is using the classroom action research on 35 eight grade students of state junior high school (SMP) 1 Tekung. The research was conducted by using two cycles including the planning, applying, observing, and reflecting stages. The data is collected by using the observation format of the learners, teachers, and questionairres. The findings are showing that the batuk learning model can improve the appreciation skill of the learners on the efforts towards the social deviation control material.
\end{abstract}

Keywords: batuk learning model, appreciation skill of learners

\section{PENDAHULUAN}

Peserta didik akan menghadapi tantangan berat karena kehidupan masyarakat global selalu mengalami perubahan setiap saat. Oleh karena itu, mata pelajaran Ilmu Pengetahuan Sosial (IPS) dirancang untuk mengembangkan pengetahuan, pemahaman dan kemampuan analisis terhadap kondisi sosial masyarakat dalam memasuki kehidupan bermasyarakat. Matapelajaran IPS disusun secara sistematis, komprehensif dan terpadu dalam proses pembelajaran menuju kedewasaan dan keberhasilan dalam hidup di masyarakat. Dengan pendekatan tersebut diharapkan peserta didik akan memperoleh pemahaman yang lebih luas dan mendalam pada bidang ilmu yang berkaitan (Permendiknas No 22 Tahun 2006 tentang Standar Isi).

Materi matapelajaran IPS Kelas VIII semester genap yang sesuai dengan Standar kompetensi dan kompetensi dasarnya adalah bentuk-bentuk hubungan sosial, pranata sosial dalam kehidupan masyarakat dan upaya pengendalian penyimpangan sosial. Sejatinya materi IPS Kelas VIII semester genap bertujuan untuk 
menyadarkan peserta didik tentang pentingnya hubungan sosial dalam masyarakat dan memberikan pemahaman kepada peserta didik untuk berlaku sesuai dengan norma dan pranata sosial yang berlaku dalam masyarakat. Tujuan lain adalah untuk menyadarkan peserta didik pada bahaya dari perilaku yang menyimpang dari norma dan pranata yang berlaku dalam masyarakat. Dengan kata lain materi menuntut adanya perubahan perilaku, persepsi dan apresiasi peserta didik terhadap masalah-masalah sosial di masyarakat.

Materi pokok seperti tesebut di atas, sangat mudah ditemui di lingkungan peserta didik karena menyangkut kehidupan yang setiap hari dialami peserta didik. Materi yang demikian apabila disajikan dengan ceramah, akan dirasa kurang menarik bagi peserta didik. Sebagian peserta didik merasa monoton dan membosankan karena sudah banyak ditemui dalam kehidupan peserta didik di lingkungan keluarga, tayangan televisi dan berita di koran.

Uraian di atas seringkali terjadi di kelas. Sebagian peserta didik pernah melanggar tata tertib sekolah termasuk terlibat miras dan pil koplo. Pada pertemuan sebelumnya yaitu pranata sosial dalam kehidupan masyarakat, sebagian peserta didik kurang antusias mengikuti bahkan cenderung untuk mengabaikan. Mereka yang kebetulan duduk berdekatan tampak asyik berdiskusi sendiri. Kegiatan pembelajaran tidak diikuti dengan sepenuh hati, apresiasi peserta didik terhadap pembelajaran rendah.

Kondisi demikian mendorong untuk dilakukan wawancara untuk mengetahui penyebabnya. Hasil wawancara terhadap beberapa peserta didik diperoleh informasi bahwa mereka asyik mendengarkan cerita dari seorang peserta didik pelaku pelanggaran. Peserta didik lebih tertarik dengan cerita tentang pelanggaran yang pernah dilakukan. Peserta didik memberikan atensi lebih besar terhadap cerita temannya daripada kegiatan pembelajaran.

Berangkat dari pengalaman di atas, perlu metode penyajian yang menarik yaitu dengan lebih melibatkan peserta didik dalam pembelajaran dan dapat mengubah perilaku, persepsi dan apresiasi peserta didik. Perubahan kondisi individu tersebut diperoleh dari proses belajar. Perubahan kondisi itu berupa perubahan tingkah laku, perubahan sikap, perubahan pengetahuan yang berbeda dari sebelumnya. Menurut Bloom bahwa hasil dari proses pembelajaran adalah kemampuan peserta didik sebagai pebelajar yang meliputi kemampuan afektif, kognitif dan psikomotor (Dimyati dan Mudjiono, 2009; Usman, 2006; Syah, 2005, dan Sudjana, 2006).

Kemampuan afektif berhubungan dengan sikap peserta didik terhadap masalah dan fenomena. Sikap peserta didik bisa berupa penyampaian tanggapan, kritik, saran, pujian dan pengahargaan. Sikap yang demikian merupakan bentuk apresiasi peserta didik. Kemampuan dalam menyampaikan tanggapan, kritik, saran, pujian dan pengahargaan perlu dikembangkan pada peserta didik. Menurut Hilman (2008) Apresiasi itu sendiri merupakan kegiatan mengenali, menilai, dan menghargai yang biasanya berupa hal yang positif, tetapi juga bisa yang negatif. Apresiasi terbagi tiga yaitu berupa kritik, pujian, dan saran.

Dalam penelitian ini, diterapkan Pembelajaran Role Play ala Tukul yang selanjutnya disebut dengan Model Batuk (belajar ala Tukul). Pembelajaran ini merupakan permainan peran yang menggunakan setting situasi seperti acara sebuah stasiun televisi swasta yang dipandu 
oleh Tukul Arwana. Dengan situasi yang tertentu dan sangat akrab dengan peserta didik karena sering ditayangkan di media massa, peserta didik lebih mudah untuk menirukan dan melakukannya. Menurut De Porter (2007), role play dapat memberikan semacam hidden practise yang berarti peserta didik tanpa sadar dapat menguasai materi dan mengalami perubahan sikap melalui pendapat dan ucapan yang disampaikan. Sebagai sebuah permainan, role play juga memberikan rasa senang kepada peserta didik. Permainan adalah dunia peserta didik, Role play merupakan pengalih dari dunia peserta didik menuju dunia kita (dunia pembelajaran). Cara ini dapat menimbulkan rasa ingin mencoba, lebih menyenangkan dan menarik bagi peserta didik (Arifin, 2008)

Menurut Hamalik (2004) bermain peran adalah salah satu model pembelajaran interaksi sosial yang menyediakan kesempatan kepada murid untuk melakukan kegiatan-kegiatan belajar secara aktif dengan personalisasi. Role playing sering di maksudkan sebagai suatu bentuk aktifitas dimana pembelajaran membayangkan dirinya seolah-olah berada di luar kelas dan memainkan orang lain saat menggunakan bahasa tutur (Zaini, 2007). Para pemain memilih aksi tokohtokoh mereka berdasarkan karakter tokoh tersebut, dan keberhasilan aksi mereka tergantung dari sistem peraturan permainan yang telah ditentukan.

Memperhatikan paparan tersebut, dalam penelitian ini dikemukakan permasalahan sebagai berikut:(1) bagaimana peran Pembelajaran Model Batuk dalam meningkatkan apresiasi peserta didik Kelas VIII pada kegiatan pembelajaran? dan (2) bagaimana peran Pembelajaran Model Batuk dalam meningkatkan apresiasi peserta didik Kelas VIII terhadap upaya pengendalian penyimpangan sosial?

\section{METODE}

Penelitian ini merupakan penelitian tindakan kelas. Tindakan direncanakan dalam dua siklus, dengan dua pertemuan tiap siklus. Siklus tindakan dimulai identifikasi masalah, dilanjutkan dengan perencanaan tindakan. Tahap berikutnya adalah pelaksanaan tindakan disertai pengamatan yang hasilnya menjadi bahan refleksi. Berdasarkan hasil refleksi dapat diperoleh dasar untuk memutuskan perlunya dilakukan tindakan lanjutan pada siklus 2 atau tidak.

Penelitian dilakukan pada mata pelajaran IPS berdasarkan kurikulum 2006, dengan materi Pengendalian Penyimpangan Sosial. Pembahasan materi tersebut selama 4 kali pertemuan selama Bulan Mei 2014. Penelitian ini dilakukan terhadap peserta didik kalas VIII SMP Negeri 1 Tekung dengan jumlah 35 Peserta didik yang terdiri atas 20 peserta didik putra dan 15 peserta didik putri. Kondisi peserta didik sangat heterogen baik dari segi akademis, geografis maupun ekonomis. Heterogenitas kelas VIII melebihi daripada kelas yang lain, sehingga merupakan kelas yang paling representatif dan paling kompleks permasalahannya. Sebagian dari peserta didik kelas ini pernah melanggar tata tertib sekolah berkaitan dengan miras dan pil koplo.

Instrumen penelitian yang digunakan meliputi adalah lembar pengamatan, angket dan lembar penilaian simpulan. Secara rinci dapat diikuti seperti dalam tabel berikut. Dari tabel berikut, telah tampak saturasi data pada perhatian peserta didik dan efektifitas model batuk. Saturasi data diperlukan untuk menjaga tingkat validitas. Saturasi data diperoleh dengan cara triangulasi melalui beberapa instrumen (PPPM SLTP, 2003). Sementara itu validitas instrumen dilakukan dengan pengujian guru sejawat. 


\section{HASIL DAN PEMBAHASAN}

Siklus pertama terdiri atas dua pertemuan x 40 menit dengan materi pembelajaran yaitu upaya pengendalian penyimpangan sosial. Langkah-langkah dalam perencanaan antara lain: (1) membentuk kelompok dengan 5 s.d. 6 orang anggota; (2) menugaskan kepada kelompok untuk menentukan tokoh yang harus diperankan yang terdiri atas Tukul dan 5 orang tamunya (pelaku penyimpangan 2 orang, orang tua, anggota masyarakat dan polisi/tokoh agama); (3) menjelaskan tujuan, materi dan topik yang diperbincangkan serta aturan pembelajaran model batuk: (4) menugaskan kepada peserta didik menyusun skenario yang ditulis pada "laptop kardus” sebagai panduan.

Siklus kedua terdiri atas dua pertemuan x 40 menit dengan materi pembelajaran yang sama yaitu upaya pengendalian penyimpangan sosial. Langkah-langkah dalam perencanaan siklus II sebagian besar masih sama dengan siklus I namun dilakukan penambahan antara lain: (1) menunjuk kelompok yang akan bermain sehari sebelumnya untuk dapat mempersiapkan diri lebih awal, sehingga menambah kepercayaan diri saat berdialog; (2) menyiapkan wareless untuk memperkuat suara saat dialog sehingga menjangkau seluruh audiens agar lebih fokus. (3) mengingatkan dan memotivasi pemeran Tukul untuk memanfaatkan yel-yel batuk dan menerikkan "kembali ke laptop" saat memulai dialog; (4) menyiapkan dan memilih lagu sebagai pengiring permainan untuk mengurangi ketegangan ketika berperan sebagai tokoh pada batuk.

Pembelajaran dibuka dengan menanyakan materi dan kegiatan pembelajaran pertemuan sebelumnya. Selanjutnya memotivasi peserta didik dengan menyampaikan pentingnya pembelajaran model "batuk." Guru meneriakkan yel-yel: "batuuk!" dan dijawab oleh seluruh peserta didik dengan: "belajar ala tukul” sambil menirukan gerakan Tukul menggosok rambut, melingkari telinga dan memajukan bibir serta tepuk tangan keras.

Pada kegiatan inti, peserta didik melakukan permainan sesuai materi dan aturan yang sudah ditetapkan dengan topik yang dipilih masing-masing kelompok. Ada tiga kelompok yang mempraktekkan model batuk pada siklus I dan II. Masingmasing kelompok pada siklus I bermain sekitar 9-12 menit dengan topik penyalahgunaan pil koplo, miras dan tawuran. Siklus II, masing-masing kelompok bermain sekitar 10 s.d. 15 menit dengan topik penyalahgunaan narkoba, seks diluar nikah dan pencurian. Sisa waktu dimanfaatkan untuk menyimpulkan materi dan refleksi kegiatan pembelajaran.

Selama jalannya batuk dilakukan pengamatan dan memberikan bantuan dan pengarahan agar batuk berjalan lancar. Motivasi diberikan kepada peserta didik yang memerankan tokoh sebagaimana telah ditetapkan. Audiens juga dimotivasi untuk tetap mengikuti dan memperhatikan dialog temannya di depan kelas. Guru memotivasi peserta didik dengan memberikan contoh beryel-yel yang disambut oleh seluruh peserta didik dengan antusias dan kompak. Guru masih memberi motivasi kepada peserta didik pemeran tokoh yang kurang percaya diri dalam menggunakan wairles. Guru juga bertindak sebagai DJ musik bakcground untuk mengurangi ketegangan.

Dialog antar pemeran tokoh dapat diikuti audiens sehingga materi dan pesan tersampaikan. Salah satu pesan penting dari testimoni peserta didik yang pernah merasakan akibat dari pil koplo bagi keluarganya. Saat pemeran pelaku penyimpangan yang testimoni diwawancarai 
oleh si Tukul, audiens memperhatikan secara serius. Meskipun masih ada yang kurang percaya diri namun dialog berjalan lancar dan lebih alami. Tampak beberapa peserta didik melakukan dialog improvisasi secara spontan yang malah mengundang tawa audiens. Pemeran Tukul juga telah dapat mengatasi situasi dengan yel-yel batuk dan "kembali ke laptop". Respon audiens lebih terarah pada materi dialog apalagi yang dilakukan dengan kocak.

Pengamatan dilakukan terhadap guru dan peserta didik baik sebagai pelaku peran maupun peserta didik sebagai audiens. Dari pengamatan terhadap guru diperoleh data bahwa guru belum mengetahui kemampuan peserta didik untuk memerankan tokoh pada batuk. Guru sering sekali memberi motivasi kepada peserta didik pelaku peran untuk lebih percaya diri dan fokus pada materi dialog. Guru juga sering mengarahkan audiens untuk tidak berlebihan dalam merespon tingkah pelaku sehingga mengganggu jalannya batuk.

Hasil pengamatan terhadap peserta didik antara lain peserta didik masih tampak kurang percaya diri karena ditertawakan oleh temannya. Dialog dilakukan dengan suara pelan dan kurang menarik perhatian audiens. Pemeran Tukul kurang mengajak audiens lebih fokus sehingga mengganggu jalannya batuk. Yelyel dan idiom yang sering dilakukan Tukul di acara TV tidak ditirukan. Hal ini menimbulkan situasi yang kurang semangat dan kurang terkendali. Respon audiens masih belum terarah pada materi dialog tetapi lebih pada tingkah yang lucu saja.

Pengamatan juga dilakukan dengan menggunakan format pengamatan. terhadap aspek apresiasi peserta didik baik apresiasi terhadap batuk maupun terhadap pengendalian penyimpangan sosial. Adapun hasilnya sebagaimana terinci pada tabel berikut:

Tabel 1: Rekapitulasi Hasil Pengamatan

\begin{tabular}{clcccc}
\hline \multirow{2}{*}{ NO } & \multirow{2}{*}{$\begin{array}{c}\text { ASPEK APRESISASI BATUK YANG } \\
\text { DIAMATI }\end{array}$} & \multicolumn{2}{c}{ Siklus I } & \multicolumn{2}{c}{ Siklus II } \\
\cline { 3 - 6 } & \multicolumn{1}{c}{ Rerata } & $\%$ & Rerata & $\%$ \\
\hline 1 & $\begin{array}{l}\text { Apresiasi Peserta didik terhadap } \\
\text { Pembelajaran }\end{array}$ & 15,8 & 45,1 & 21 & 59,5 \\
\hline 2 & $\begin{array}{l}\text { Apresiasi Peserta didik terhadap } \\
\text { Pengendalian Penyimpangan Sosial }\end{array}$ & 8,8 & 25,1 & 13,8 & 39,4 \\
\hline
\end{tabular}

Catatan: Jumlah peserta didik $=35$

Berdasaarkan tabel di atas terlihat bahwa rerata kemampuan apresiasi peserta didik rendah yaitu 45,1\% terhadap pembelajaran model batuk dan hanya 25,1\% apresiasi peserta didik terhadap pengendalian penyimpangan sosial. Hasil pengamatan dan wawancara pada siklus I diperoleh beberapa kekurangan dan celah yang harus ditutupi agar batuk bisa lebih optimal. Peserta didik kurang fokus pada materi dialog tapi masih sibuk sendiri dan terlalu tegang. Suara pemeran tokoh kurang keras mengakibatkan dialog tidak diikuti oleh audiens dan pesan kurang tersampaikan. Hal ini memberikan gambaran bahwa efektifitas batuk dan kemampuan apresiasi peserta didik masih rendah, baik apresiasi terhadap batuk maupun pengendalian penyimpangan sosial.

Hasil pengamatan juga menunjukkan rerata yang rendah. Ini merupakan pertanda bahwa pembelajaran dengan model batuk belum berjalan efektif. Akibatnya bahwa apresiasi peserta didik terhadap materi pembelajaran yaitu pengendalian penyimpangan sosial juga rendah. Dapat 
dikatakan pembelajaran model batuk belum berjalan optimal.

Pengamatan siklus II juga dilakukan dengan menggunakan format pengamatan. Pengamatan dilakukan terhadap aspek apresiasi peserta didik baik apresiasi terhadap batuk maupun terhadap pengendalian penyimpangan sosial. Berdasarkan hasil pengamatan, secara umum pembelajaran model batuk pada siklus II berjalan dengan lancar dan sesuai aturan. Materi dan pesan dapat tersampaikan dengan optimal. Sementara dari hasil wawancara kepada peserta didik kreativitas peserta didik muncul tanpa beban takut salah. Peserta didik tampak senang dan enjoi dalam mengikuti kegiatan pembelajaran.

Hasil pengamatan juga menunjukkan rerata yang meningkat pada siklus II dibandingkan siklus I. Apresiasi peserta didik terhadap pembelajaran model batuk meningkat dari 45,1\% pada silus I menjadi 59,5\% pada siklus II. Apresiasi peserta didik terhadap materi pembelajaran yaitu pengendalian penyimpangan sosial juga meningkat dari $25,1 \%$ pada siklus I menjadi $39,4 \%$ pada siklus II. Ini merupakan pertanda bahwa pembelajaran dengan model batuk berjalan efektif. Akibatnya bahwa apresiasi peserta didik terhadap materi pembelajaran yaitu pengendalian penyimpangan sosial juga rendah. Dapat dikatakan pembelajaran model batuk belum berjalan optimal.

Efektifitas pembelajaran model batuk dan peningkatan hasil belajar yang berupa kemampuan apresiasi peserta didik pada materi pembelajaran yaitu pengendalian peyimpangan sosial, dapat dicrosscek dengan hasil angket. Angket diisi peserta didik pada sebelum dimulai batuk dan sesudah mengikuti batuk. Angket yang dijawab peserta didik terdiri atas dua macam yaitu angket apresiasi peserta didik terhadap pembelajaran model batuk dan angket apresiasi peserta didik terhadap pengendalian penyimpangan sosial. Hasilnya dapat dicermati pada tabel berikut.

Tabel 2: Hasil Angket Kemampuan Apresiasi Peserta didik

\begin{tabular}{|c|c|c|c|c|c|}
\hline No. & Aspek Apresiasi & Rentang Skor & $\begin{array}{c}\text { Siklus I } \\
(\%)\end{array}$ & $\begin{array}{c}\text { Siklus II } \\
\text { (\%) }\end{array}$ & Kategori \\
\hline \multirow[t]{4}{*}{1.} & \multirow{4}{*}{$\begin{array}{l}\text { Pembelajaran } \\
\text { model batuk }\end{array}$} & $29-32$ & 14,2 & 34,3 & Sangat tinggi \\
\hline & & $25-28$ & 48,6 & 42,9 & Tinggi \\
\hline & & $21-24$ & 17,1 & 14,2 & Sedang \\
\hline & & $17-20$ & 20 & 8,6 & Rendah \\
\hline \multirow[t]{4}{*}{2.} & \multirow{4}{*}{$\begin{array}{l}\text { Pengendalian } \\
\text { Penyimpangan } \\
\text { sosial }\end{array}$} & $25-28$ & 5,7 & 14,2 & Sangat tinggi \\
\hline & & $21-24$ & 17,1 & 37,1 & Tinggi \\
\hline & & $17-20$ & 40 & 42,8 & Sedang \\
\hline & & $13-16$ & 37,1 & 5,7 & Rendah \\
\hline
\end{tabular}

Catatan: Jumlah peserta didik $=35$ orang

Tabel di atas menyajikan informasi adanya peningkatan kemampuan apresiasi peserta didik baik pada pembelajaran model batuk maupun pada pengendalian penyim-pangan sosial. Hal ini terbaca dari semakin menurunnya prosentase pada kategori rendah yaitu dari 20\% (siklus I) menjadi hanya 8,6\% (siklus II) untuk kemampuan apresiasi terhadap pembelajaran model batuk. Apresiasi terhadap pengendalian penyimpangan sosial juga ditemukan penurunan prosentase peserta didik pada kategori rendah yaitu dari $37,1 \%$ menjadi hanya $5,7 \%$. Data yang demikian, memperkuat hasil pengamatan terhadap kemampuan apresiasi 
peserta didik. Ini merupakan sinyal efektifitas pembelajaran model batuk juga meningkat yang diiringi dengan meningkatnya hasil belajar peserta didik yang dalam penelitian ini disebut sebagai kemampuan apresiasi peserta didik.

\section{PEMBAHASAN}

Berdasarkan analisis hasil diperoleh informasi bahwa pembelajaran model batuk dapat meningkatkan kemampuan apresiasi peserta didik terhadap pembelajaran dan pengendalian penyimpangan sosial. Hasil ini terjadi karena pembelajaran model batuk melibatkan ranah belajar dan kemampuan. Peserta didik dihadapkan pada materi pembelajaran penyimpangan sosial. Peserta didik dituntut untuk menyusun skenario (psikomotor) berdasarkan pengetahuannya (kognitif) sehinga dapat bersikap (afektif). Secara tidak langsung peserta didik dibiasakan untuk mengapresiasi suatu masalah.

Sebagaimana role play pembelajaran model batuk, menuntut keterlibatan peserta didik secara gerak, otak dan emosional. Dalam pembelajaran model batuk peserta didik harus mempersiapkan diri secara materi dan mental memerankan karakter tokoh yang terdapat di dalamnya. Secara materi peserta didik harus mempelajari, mencerna dialog dan menterjemahkannya dalam garak yang mendukung. Dengan proses yang demikian pembelajaran model batuk dapat mengubah perilaku peserta didik (De Porter, 2007)

Role Play adalah sejenis permainan gerak yang di dalamnya terdapat tujuan, aturan dan sekaligus melibatkan unsur senang. Pembelajaran role play peserta didik dikondisikan pada situasi tertentu sesuai dengan skenario. Role play seringkali dime-ngerti sebagai aktivitas pembelajaran dengan berlaku dan berperan selayaknya orang lain (Zaini, 2007)
Menurut De Porter (2007), role play dapat memberikan semacam hidden practise yang berarti peserta didik tanpa sadar dapat menguasai materi dan mengalami perubahan sikap melalui pendapat dan ucapan yang disampaikan. Sebagai sebuah permainan, role play juga memberikan rasa senang kepada peserta didik. Permainan adalah dunia peserta didik, role play merupakan pengalih dari dunia peserta didik menuju dunia kita (dunia pembelajaran).

Pada pembelajaran model batuk, peserta didik bebas menentukan bentuk dan skenario dialog. Dialog berdasarkan pengetahuan, pengalaman dan hasil diskusi antarpeserta didik, Tidak bersifat serius tapi bercanda didepan kelas. Tidak ada kriteria salah dan benar. Improvisasi dialog diutamakan muncul dari peserta didik. Sehingga peserta didik tidak tertekan dalam melakukan dialog. Skenario tertulis pada "laptop karton” dibacakan oleh pemeran Tukul, sehingga arah perbincangan dikendalikan. Peserta didik lain sebagai audiens dilibatkan dengan yel-yel yang dilontarkan oleh Tukul. Keterlibatan ini akan berakibat timbulnya apresiasi peserta didik sebagai audiens terhadap pemeran tokoh pada pembelajaran model batuk.

Hasil belajar adalah perubahan kondisi individu ayng diperoleh dari proses belajar. Perubahan kondisi itu berupa perubahan tingkah laku, perubahan sikap perubahan pengetahuan yang berbeda dari sebelumnya. Hasil dari proses pembelajaran adalah kemampuan peserta didik sebagai pebelajar yang meliputi kemampuan afektif, kognitif dan psikomotor.

Kemampuan afektif berhubungan dengan sikap pebelajar terhadap masalah dan fenomena. Sikap pebelajar bisa berupa penyampaian tanggapan, kritik, saran, pujian dan pengahargaan. Kemampuan kognitif berhubungan dengan ingatan, 
pengetahuan dan kemampuan intelektual. Dengan kata lain kemampuan kognitif adalah kemampuan memahami materi pembelajaran yang dipelajari dan menyimpannya dalam waktu tertentu. Kemampuan psikomotor sangat berhubungan dengan ketrampilan melakukan atau berbuat sesuatu berdasarkan sikap dan pengetahuannya.

Ketiga kemampuan di atas, seorang peserta didik dapat berbuat berdasarkan pengetahuan dan pendapat dan sikapnya. Termasuk peserta didik dapat memberikan kritik atau saran, mencela atau menghargai, merusak atau mendukung berdasarkan komposisi ketiga kemampuan yang dimiliki. Ketiga kemampuan tersebut pebelajar memiliki kemampuan mengapresiasi suatu masalah atau kejadian sesuai kemampuannya. Dapat disimpulkan kemampuan apresiasi merupakan hasil dari proses belajar.

\section{SIMPULAN}

Pembelajaran model batuk dapat meningkatkan kemampuan apresiasi peserta didik dalam materi upaya pengendalian penyimpangan sosial di kelas VIII SMP Negeri 1 Tekung,.

Berdasarkan hasil penelitian maka dapat dikemukakan saran sebagai berikut. Upaya peningkatan efektifitas pembelajaran di kelas guru hendaknya menggunakan metode, model dan strategi pembelajaran yang mengaktifkan peserta didik. Pemilihan dan penentuannya haruslah memperhatikan kondisi peserta didik sebagai subyek belajar dengan berusaha bersimpati dan berempati pada masalah yang dihadapi peserta didik. Ketidak nyaman peserta didik menyebabkan rendahnya apresiasi peserta didik.

\section{DAFTAR PUSTAKA}

Arifin, BZ. (2008). Pembelajaran Fisika dengan Permainan Kartu Kuartet dan Role Playing Ditinjau Dari Konsep Diri, Tesis tidak diterbitkan.

Barkley, E. dkk. (2012). Colaborative Laerning Techniques. Bandung Nusa Media

De Porter, B. (2007). Quantum Learning: membiasakan belajar nyaman dan menyenangkan. Bandung: Kaifa.

Dimyati \& Mudjiono. (2009). Belajar dan Pembelajaran. Jakarta:Rineka Cipta. Hamalik, O. (2004). Proses Belajar Mengajar. Bandung: Bumi Akasara. PPPM SLTP Jawa Timur. (2003). Pedoman Pelaksanaan Pembekalan Classroom Action Research. Surabaya: Dinas Pendidikan dan Kebudayaan Jawa Timur.

Permendiknas No 22 Tahun 2006 tentang Standar Isi

Sudjana, N. (2006). Dasar-dasar Proses Belajar Mengajar. Jakarta: Sinar Baru.

Syah, M. (2005). Psikologi Pendidikan ( Dengan Pendekatan Baru). Bandung: PT Remaja Rosdakarya.

Usman, M.U. (2006). Menjadi Guru Profesional. Bandung: PT Remaja Rosdakarya.

Zaini, H. dkk. (2007). Strategi Pembelajaran Aktif. Yogyakarta: Rineka Cipta. 